\title{
Article \\ Developing and Analyzing the Agricultural Water Poverty Index in West Iran
}

\author{
Leila Zoleikhaie Sayyar ${ }^{1}\left(\mathbb{D}\right.$, Karim Naderi Mahdei ${ }^{1, *} \mathbb{C}$, Hossein Shabanali Fami ${ }^{2}\left(\mathbb{D}\right.$ and Mahsa Motaghed ${ }^{2}$ \\ 1 Department of Agricultural Extension and Education, College of Agriculture, Bu-Ali Sina University, \\ Hamedan 6516738695, Iran; la.zolikhai@gmail.com \\ 2 Department of Agricultural Development and Management, University of Tehran, Karaj 1417935840, Iran; \\ hfami@ut.ac.ir (H.S.F.); Mahsa.Motaghed@ut.ac.ir (M.M.) \\ * Correspondence: knadery@basu.ac.ir; Tel.: +98-81-3442-5400 or +98-918-819-5863; Fax: +98-81-3442-5402
}

\section{check for}

updates

Citation: Zoleikhaie Sayyar, L.;

Naderi Mahdei, K.; Shabanali Fami,

H.; Motaghed, M. Developing and Analyzing the Agricultural Water Poverty Index in West Iran.

Sustainability 2022, 14, 1410 .

https://doi.org/10.3390/su14031410

Academic Editors:

Masoud Yazdanpanah,

Katharina Löhr, Jorge Ruiz-Menjivar,

Tahereh Zobeidi and Stefan Sieber

Received: 11 December 2021

Accepted: 18 January 2022

Published: 26 January 2022

Publisher's Note: MDPI stays neutral with regard to jurisdictional claims in published maps and institutional affiliations.

Copyright: (c) 2022 by the authors. Licensee MDPI, Basel, Switzerland. This article is an open access article distributed under the terms and conditions of the Creative Commons Attribution (CC BY) license (https:// creativecommons.org/licenses/by/ $4.0 /)$.

\begin{abstract}
Currently 60 percent of Iran's land is located in water-stressed regions, where Hamedan is known as a semi-arid province and is also a province with a high population concentration with a dominant agricultural economy. For analyzing human-related crises we need multidimensional measures and AWPI has a socio-economical dimension and multidimensional criteria for assessing status. Hence, the purpose of the present study was to develop and evaluate the water resources status in the agriculture sector of Hamedan province using AWPI as a typical area in western Iran. The present applied study was conducted to evaluate the status of water poverty in the agriculture sector of Hamedan province using the Agricultural Water Poverty Index (AWPI). This index includes five components: resources, access, use, capacity, and environment. The indicators explaining each of the five components of AWPI were collected from different literature and the data were collected using databases, statistics, and the national census of 2016. A total of five principal components and 55 indicators were developed and were used to evaluate the status of water resources. The value of the composite AWPI was developed by the weighted mean of the five principal components. The data were analyzed using SPSS and GIS software. The components, criteria, and sub-criteria of AWPI were weighted using the principal components analysis. The mean AWPI for Hamedan province was 40.55 , which indicates that the province is placed in the middle to high water poverty status and this poverty is mostly due to the components of resources, capacity, access, and use.
\end{abstract}

Keywords: water management; sustainability; agricultural sector; components of AWPI; Hamedan-Iran

\section{Introduction}

Assessing water resource status is a prerequisite of sustainable water management and plays an important role in achieving sustainable agriculture. Also, economic poverty is strongly related to water poverty [1]. One of the new tools designed to evaluate sustainable water management is the Water Poverty Index (WPI). This index has been used by many scholars in recent studies on the assessment of water scarcity in a region. According to Koirala, et al. [2], WPI offers a robust and comprehensive tool to assess water stress at various spatial scales. The concept of the WPI was first introduced by Sullivan [3] and Lawrence, et al. [4] indicating it as the degree to which water scarcity impacts the human population. Sullivan [3], as one of the principal theorists in this area, defined poverty as a deprivation of basic capabilities, not just the lack of income. The WPI includes a range of components related to water availability parameters for drinking and food production needs and individuals, problems facing reliable access, and the use of water [4-8]. In recent years, the WPI has been used to identify the mechanisms for solving the water crisis all over the world i.e., in Egypt [9], Nepal [10,11], India [12], South Africa [13], Tunisia [14], China [6], Vietnam [15], Nigeria [16] and Benin [17].

Accordingly, the WPI consists of five components; access to water, water quantity, quality and distribution of water use (household, food, and production), the capacity of 
water management, and the environmental aspects $[4,18]$. The WPI is a simplified form of three sub-indicators of access, capacity, and the environment with unequal weights in the physical, social, economic, and environmental dimensions which helps to identify places where there are not sufficient water resources and so are in water poverty status $[10,19]$. This index could be used at the local [14,20,21], basin [11,15,22], district [17,23], national [24] and international [4] levels.

This index is a measure of abundance or poverty of available water resources in an area for domestic needs (drinking) and demand for food products proportional to the population size [14,25]. According to various scholars [3,4,26,27], this index is one of the most comprehensive measures in this regard, because in addition to discussing the quantity and quality of water resources, the management of these resources is also evaluated and comprehensive analysis of the water role in the sustainable development is provided.

In the agriculture sector, this index, which is known as Agricultural Water Poverty Index (AWPI), is used as a tool for evaluating water status and poverty in the agriculture sector [28-30]. Hence, the AWPI is an interdisciplinary tool that includes key dimensions of an agricultural system that pays particular attention to available water resources and physical access to water [12,31]. Therefore, different hydrological, economic, and social indicators need to be considered and each index for measuring poverty in the agriculture sector should take into account all these dimensions simultaneously $[5,9,32,33]$. The AWPI utilizes the human, social and economic capabilities of farmers for the effective use of water for productive and environmental uses [34]. One of the capabilities of this index is its power to compare the conditions of water poverty in different areas [13,35,36]. Ranking of agricultural areas based on this measure leads to better water management as well as adopting water policies with higher effectiveness $[16,32,37,38]$. The AWPI, like the WPI, consists of five components: resource, access, use, capacity, and environment [39].

The "Resources" component is used to measure the amount of surface water and groundwater resources available to farmers in an area [30]. The "Access" component is related to the access of farmers to these resources, as well as the potential and infrastructure of agricultural land for the effective use of available water [31]. The "Use" component includes the physical efficiency of water consumption by the farmer and their ability to use agricultural water effectively [26,28,29]. The "Capacity" component measures the human, social and real capacity and capital of farmers to optimally use water [40-42]. Jaren and Mondal [43] reveal that to be more water-secure, social components of water poverty must be improved. The evidence suggests that income is an important driver of improving farmers' capacity and reducing poverty in rural areas $[4,17,20,42]$. Finally, the "Environment" component describes how environmental factors such as climate change affects the availability of water and its quality such as its salinity [26].

In Iran, Forouzani and Karami [31] used AWPI in a southern area of Iran to assess water scarcity and its effect on food production. Furthermore, Zarafshani and Saadvandi [44] used AWPI in Kermanshah province. They assessed AWPI components (resources, access, use, capacity, and environment) to draw the agricultural water poverty map originally suggested by Lawrence, Meigh and Sullivan [4] and Sullivan, Meigh and Giacomello [42]. This study emphasized developing a comprehensive index in assessing agricultural water poverty through combining some new indicators of sustainability making it a more robust and extensive AWPI. The application of AWPI to assess the sustainability of water management in agriculture makes it an innovative tool to analyze water management problems. The present study was conducted in Hamedan province, which is located in the west part of Iran. The climate of this region is semiarid with annual precipitation of $300 \mathrm{~mm}$ on average. The excessive use of groundwater aquifers, especially by agricultural wells, has caused a drastic reduction in the quantity of water in the reservoirs. The volume of drainage of these aquifers based on the latest estimates was 2.5 billion cubic meters in which the number of wells excavated was about 13,000 (Hamedan Governorate, 2011). Therefore, the status of water resources of the province in the agriculture sector is undesirable thus making agriculture more vulnerable. So, we focus on Hamedan, a province where natural dryness 
is mixed with rapid socio-economic development, growing water demand particularly for agriculture, and unsustainable land and water management. Hence, the main purpose of the study was to develop and evaluate the water resources status in the agriculture sector of Hamedan province using AWPI as a typical area in western Iran.

\section{Materials and Methods}

The main aim of this applied study was to develop and assess agricultural water poverty in Hamedan province in Iran, a province which has seen severe consequences of climate change. The data were collected from databases such as Agricultural Statistics, Agricultural Jihad Organization, Regional Water Company of Hamedan Province, and National censuses. The study investigated the status of agricultural water resources. Since the region has some location-specific characteristics, it was necessary to modify some of the suggested indicators of AWPI and adapt them to the study area realities (Hamedan province). For this purpose, in most of the components of WPI, some indicators were removed, and some others were added to suit the model to the study location.

The components, criteria, and sub-criteria of AWPI were weighed using principal components analysis by SPSS software. After calculating the five components using Equations (3), (6), (7), (10) and (11). The overall AWPI was calculated using Formula 12. Finally, critical points and critical areas were identified for water poverty, and the causes of agricultural water poverty were distinguished using the GIS and the AWPI map. A total of five principal components and 55 indicators were used for the evaluation of water resources status in the agriculture sector of Hamedan province. The location of the area (Hamedan province) is shown in Figure 1.

The location of the area (Hamedan province) is shown in Figure 1. This figure indicates the dispersion of cultivated lands in each county of the province and the latest production value of agricultural produce in the province [45].

The methods of developing the AWPI components and sub-components are presented below.

\subsection{Calculating Resources (R)}

The Resource component consists of two sub-components of "surface water" and "groundwater", each of which in turn contains different indicators. The final value of the resource component of each county depends on the calculated value of the sub-components and associated indicators. To achieve the values of sub-components, available surface water, and groundwater, the values of each of the indicators were calculated and standardized, and then the mean weight of the relevant indicators was calculated. Therefore, based on the weights assigned, water resource indicators $\left(R_{1}\right.$ and $\left.R_{2}\right)$ were calculated as follows (Equations (1) and (2)):

$$
\begin{aligned}
R_{1} & =\frac{\sum\left(W R_{1 i} X_{n} R_{1 i}\right)}{\sum W R_{1 i}} \\
R_{2} & =\frac{\sum W R_{2 i} X_{n} R_{2 i}}{\sum W R_{2 i}}
\end{aligned}
$$

$X_{n}$ : the standardized values of each indicator in the resource component, $R_{1}$ : the value of sub-component of surface water resources, $R_{2}$ : the value of sub-component of the groundwater resource, $W R_{1}$ : the numerical weight of surface water resources, $W R_{2}$ : the numerical weight of groundwater resources.

The resource component $(R)$ was calculated based on the weighted mean of two subcomponents: surface water resources $\left(R_{1}\right)$ and groundwater resources $\left(R_{2}\right)$ (Equation (3)):

$$
R=\frac{\left\{\left(W R_{1} \times R_{1}\right)+\left(W R_{2} \times R_{2}\right)\right\}}{\left(W R_{1} \times W R_{2}\right)}
$$




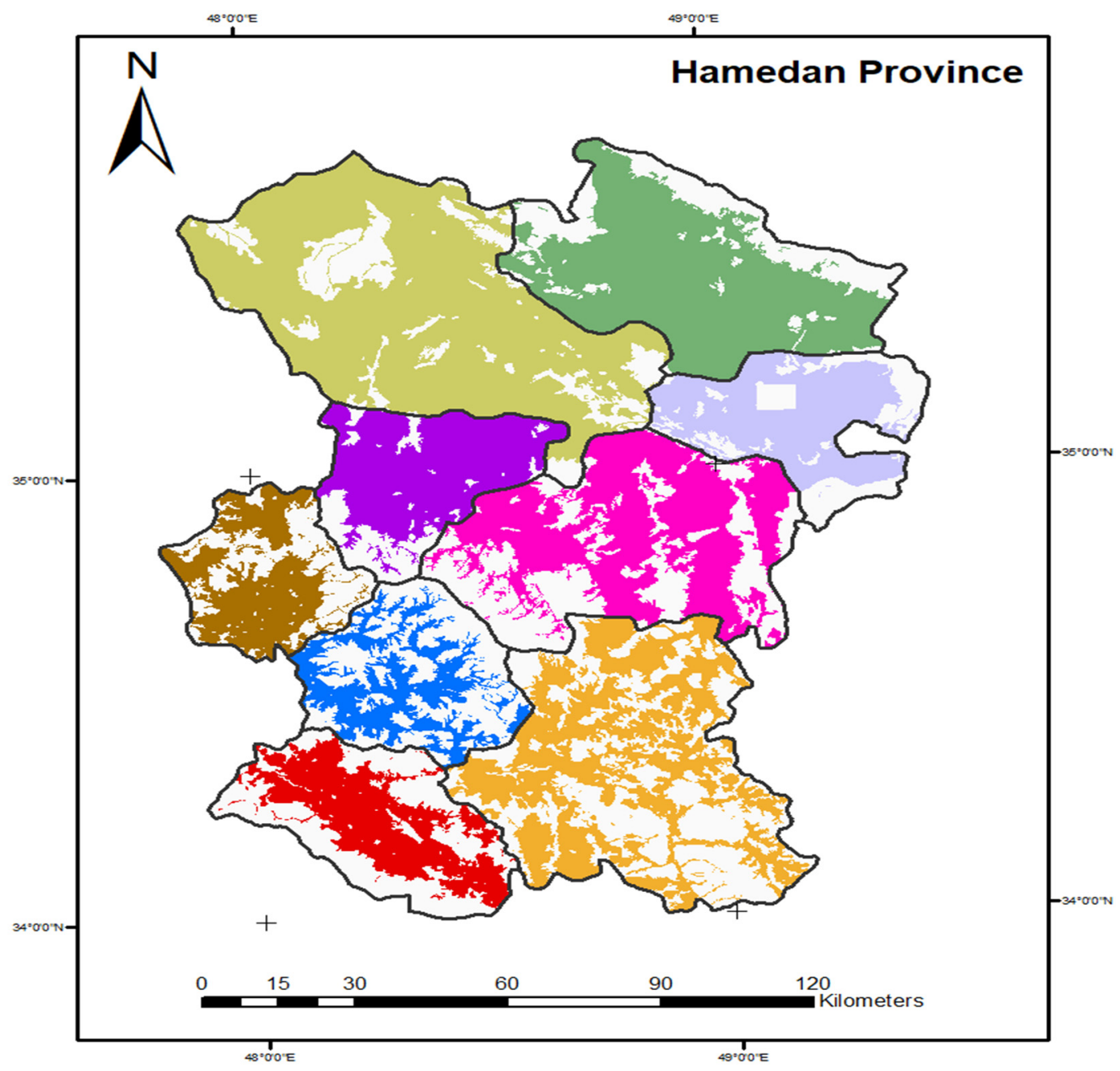

\section{Legend}

\begin{tabular}{|c|c|c|c|}
\hline Color & County & $\begin{array}{l}\text { Land Under } \\
\text { Cultivation } \\
\text { (ha) }\end{array}$ & $\begin{array}{l}\text { Production Value of } \\
\text { Agriculture Sector } \\
\text { (Million Rials) }\end{array}$ \\
\hline $28^{n}$ & Hamedan & 116385 & 29193586 \\
\hline+5 & Bahar & 73303 & 22916257 \\
\hline$\therefore=$ & Toyserkan & 35765 & 24550634 \\
\hline$y^{2}$ & Kabudarahang & 218118 & 16017792 \\
\hline sciand & Malayer & 109368 & 29972086 \\
\hline 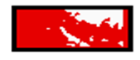 & Nahavand & 59691 & 29977383 \\
\hline$y$ & Asadabad & 48997 & 18649895 \\
\hline 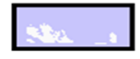 & Famenin & 74338 & 5861675 \\
\hline 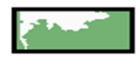 & Razan & 136209 & 22465448 \\
\hline
\end{tabular}

Figure 1. The locations and agricultural production values of the counties in the study area. 


\subsection{Calculating Access ( $A$ )}

The Access component is composed of the two sub-components of "Farmers Access to Water" and "Land Potential for Access to Water". This component specifies the access of available water for agricultural purposes. The sub-component of "Farmers Access to Water" $\left(A_{1}\right)$ consists of nine indicators and the sub-component of "Land Potential for Access to Water" $\left(A_{2}\right)$ consists of four indicators. The values of sub-components $A_{1}$ and $A_{2}$ were calculated as follows (Equations (4) and (5)):

$$
\begin{aligned}
& A_{1}=\frac{\sum\left(W A_{1 i} \times X_{n} A_{1 i}\right)}{\sum W A_{1 i}} \\
& A_{2}=\frac{\sum\left(W A_{2 i} \times X_{n} A_{2 i}\right)}{\sum W A_{2 i}}
\end{aligned}
$$

$X_{n}$ : the standardized values of each indicator in the access component, $A_{1}$ : the value of Farmer's Access to Water sub-component, $A_{2}$ : the value of Land Potential for Access to Water sub-component, $W A_{1}$ : the numerical weight of Farmer's Access to Water sub-component, $W A_{2}$ : the numerical weight of the Land Potential for Access to Water sub-component.

To achieve the final value of the access component for each farmer, Equation (6) was used:

$$
A=\frac{\left\{\left(W A_{1} \times A_{1}\right)+\left(W A_{2} \times A_{2}\right)\right\}}{\left(W A_{1}+W A_{2}\right)}
$$

\subsection{Calculating Use (U)}

The Use component is the third component of the agricultural water poverty index that shows available water use efficiency. This component consists of five indicators, which after the calculation of the standard values and according to the assigned weights, Equation (7) was used to calculate the final value of the Use component $(U)$.

$$
U=\frac{\sum\left(W U_{i} \times X_{n} U_{i}\right)}{\sum W U_{i}}
$$

$X_{n}$ : the standardized values of each indicator in the Use component, $U$ : the value of the Use component, $W U$ : the numerical weight of the Use component.

\subsection{Calculating Capacity (C)}

The Capacity component is composed of two sub-components of "Real Capital" and "Human and Social Capital". The sub-component of "real capital" consists of 15 indicators and the sub-component of "human and social capital" includes nine different indicators. The final value of the Capacity component is calculated from the values of the respective indicators, which first standardized the values of the indicators, and then the mean weights were calculated. Using the assigned weights and the final value of each indicator, the total value of the Capacity component was determined using the following equations (Equations (8)-(10)):

$$
\begin{gathered}
C_{1}=\frac{\sum\left(W C_{1 i} \times X_{n} C_{1 i}\right)}{\sum W C_{1 i}} \\
C_{2}=\frac{\sum\left(W C_{2 i} \times X_{n} C_{2 i}\right)}{\sum W C_{2 i}} \\
C=\frac{\left\{\left(W C_{1} \times C_{1}\right)+\left(W C_{2} \times C_{2}\right)\right\}}{\left(W C_{1}+W C_{2}\right)}
\end{gathered}
$$

$X_{n}$ : the standardized values of each indicator of the Capacity component, $C_{1}$ : the value of Real Capital sub-component, $C_{2}$ : the value of Social and Human Capital sub-component, $C$ : the value of the Capacity component, $W C_{1}$ : The numerical weight of Real Capital sub-component, $W C_{2}$ : the numerical weight of Social and Human Capital sub-component. 


\subsection{Calculating Environment}

The Environment component is the last component of the Agricultural Water Poverty Index and it examines the factors affecting the quality of water in the agriculture sector. This component consists of four indicators. After calculating the standard values of these four indicators, and considering the weights assigned to them, Equation (11) was used to calculate the final value of the Environment component $(E)$.

$$
E=\frac{\sum\left(W E_{i} \times X_{n} E_{i}\right)}{\sum W E_{i}}
$$

$X_{n}$ : the standardized values of each indicator of the Environment component, $E$ : the Environment component, $W E$ : the numerical weight of the environment component.

The total value of AWPI was calculated by the means weight of the five principal components and then multiplied by 100 .

\subsection{AWPI Calculation Steps}

The Agricultural Water Poverty Index was calculated at several steps as follows:

(1) Selecting of indicators: the indicators of each component were selected through reviewing previous papers, reports, statistics, and frameworks.

(2) Calculating the numerical value of each indicator.

(3) Weighing of indicators: to prepare the composite index map, it is sometimes necessary to calculate the weight and degree of importance for each indicator. In this study, principal components analysis (PCA) by SPSS software was used to weight the indicators. PCA is one of the most accepted weighting methods and several studies have used PCA for the weighting of indicators $[46,47]$.

(4) Normalization: given that the unit of measurement of the indicators was different. A re-scaling technique was used to normalize them as shown in the Equation (12):

$$
n_{i}=\frac{\left(X_{i}-X_{\min }\right)}{\left(X_{\max }-X_{\min }\right)}
$$

where $n$ is the normalized indicator, $X_{i}$ represents the factor in raw form, and $i$ represents the indicator being normalized. The $X_{\max }$ relate to the maximum value in the indicator and $X_{\min }$ relate to the minimum value in the indicator.

(5) The weight of each indicator is multiplied by the scale difference of indicators: at this stage, after removing the difference in the scale of the indicators, it is multiplied by the weight assigned to them.

(6) Calculating composite AWPI for each county and province: at the sixth stage, the values of sub-components and components were calculated, and finally, the composite Agricultural Water Poverty Index was calculated using the Forouzani et al. (2013) Equation. Accordingly, AWPI was calculated by the Equation (13) and using the assigned weights:

$$
A W P I=\frac{[(W R \times R)(W A \times A)+(W U \times U)+(W C \times C)+(W E \times E)]}{[W R+W A+W U+W C+W E] \times 100}
$$

$W$ : weight of each component.

(7) Preparation of AWPI zoning map: At the last stage, the map of agricultural water poverty was drawn according to the counties value.

The components, sub-components, and indicators of the Agricultural Water Poverty Index are given in Table 1. 
Table 1. The components, sub-components, and indicators of the Agricultural Water Poverty Index.

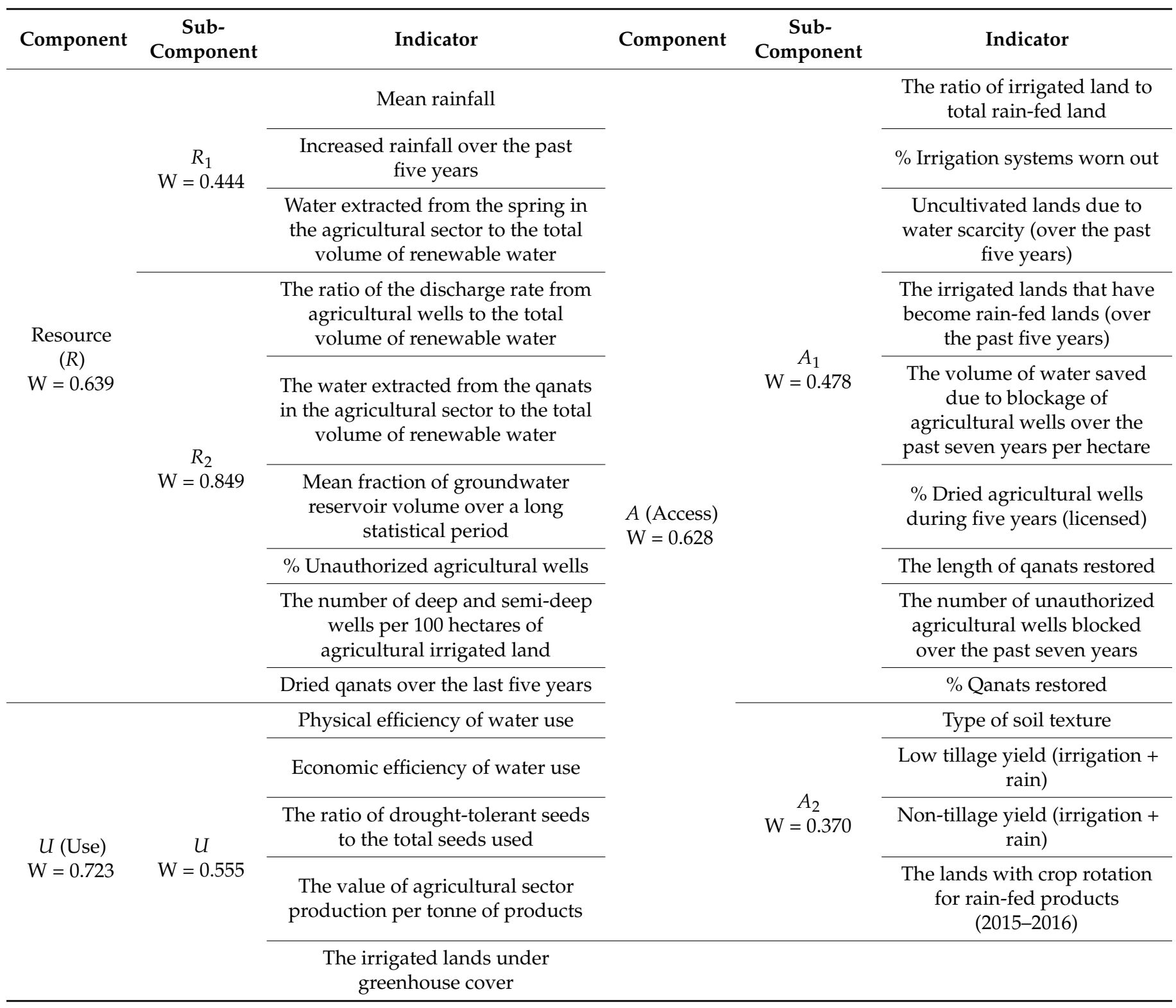


Table 1. Cont.

\begin{tabular}{|c|c|c|c|c|c|}
\hline Component & $\begin{array}{l}\text { Sub- } \\
\text { Component }\end{array}$ & Indicator & Component & $\begin{array}{l}\text { Sub- } \\
\text { Component }\end{array}$ & Indicator \\
\hline \multirow{15}{*}{$\begin{array}{c}C \\
\text { (Capacity) } \\
W=0.712\end{array}$} & \multirow{15}{*}{$\begin{array}{c}C_{1} \\
W=0.749\end{array}$} & Canal and watercourse lining & \multirow{9}{*}{ C } & \multirow{9}{*}{$\begin{array}{c}C_{2} \\
\mathrm{~W}=0.317\end{array}$} & Literacy rate of farmers (2014) \\
\hline & & Integrated modern land area & & & $\begin{array}{l}\text { Educational classes held in the } \\
\text { field of water management }\end{array}$ \\
\hline & & Using pipe system for water delivery & & & $\%$ Users of rural cooperatives \\
\hline & & $\begin{array}{l}\text { Invested income for improving } \\
\text { irrigation system by farmer }\end{array}$ & & & $\begin{array}{l}\% \text { Users of agricultural } \\
\text { cooperatives }\end{array}$ \\
\hline & & Farmer's land under drought insurance & & & $\begin{array}{l}\% \text { Users of water } \\
\text { use organizations }\end{array}$ \\
\hline & & $\begin{array}{l}\text { Utilization of insurance (drought) of } \\
\text { agricultural products }\end{array}$ & & & $\begin{array}{l}\text { The number of rural } \\
\text { production cooperatives per } \\
100 \text { villages }\end{array}$ \\
\hline & & $\begin{array}{l}\text { Reduced level of insurance over the } \\
\text { last five years }\end{array}$ & & & $\begin{array}{l}\text { The number of agricultural } \\
\text { cooperatives per } 100 \text { villages }\end{array}$ \\
\hline & & $\begin{array}{l}\text { The average area of agricultural land } \\
\text { utilization with land }\end{array}$ & & & $\begin{array}{c}\text { Number of water use } \\
\text { organizations per } 100 \text { villages }\end{array}$ \\
\hline & & $\begin{array}{l}\text { The irrigated lands covered by } \\
\text { modern irrigation }\end{array}$ & & & $\begin{array}{l}\text { The lands covered by } \\
\text { rural cooperatives }\end{array}$ \\
\hline & & Agricultural wells with smart meters & \multirow{6}{*}{$\begin{array}{l}E \text { (Environ- } \\
\text { ment) } \\
W=0.797\end{array}$} & \multirow{6}{*}{$\begin{array}{c}E \\
\mathrm{~W}=0.851\end{array}$} & $\begin{array}{l}\text { The quality of surface water } \\
\text { in terms of salinity }\end{array}$ \\
\hline & & $\begin{array}{l}\text { The number of existing quotas per } \\
100 \text { farmers }\end{array}$ & & & $\begin{array}{c}\text { The quality of groundwater in } \\
\text { terms of salinity }\end{array}$ \\
\hline & & $\begin{array}{l}\text { The number of diversion lines } \\
\text { available per 10,000 farmers }\end{array}$ & & & $\begin{array}{l}\text { Fertilizer consumption } \\
\text { (distribution of various } \\
\text { chemical fertilizers) }\end{array}$ \\
\hline & & $\begin{array}{l}\text { The number of available water } \\
\text { storage pools per } 1000 \text { farmers }\end{array}$ & & & \multirow{3}{*}{$\begin{array}{l}\text { Pesticide use (the amount of } \\
\text { chemical pesticide sold) }\end{array}$} \\
\hline & & Improved gardens area & & & \\
\hline & & $\begin{array}{l}\text { Mechanized agricultural } \\
\text { land percentage }\end{array}$ & & & \\
\hline
\end{tabular}

\section{Results}

\subsection{Analysis of Agricultural Water Poverty Index Components}

The final values of AWPI in different counties are shown in Table 2.

Table 2. AWPI of different counties.

\begin{tabular}{ccccccccccc}
\hline County & Toyserkan & AsadAbad Hamedan & Razan & Bahar & Nahavand & $\begin{array}{c}\text { Kabudar } \\
\text { Ahang }\end{array}$ & Famenin & Malayer & Province \\
\hline AWPI & 56.03 & 48.69 & 47.48 & 45.9 & 44.02 & 42.60 & 41.79 & 38.99 & 38.51 \\
Rank & 1 & 2 & 3 & 4 & 5 & 6 & 7 & 8 & 9 & 40.55 \\
\hline
\end{tabular}

According to the results, the mean AWPI for Hamedan province was 40.55. This indicates that the province suffers from moderate to high agricultural water poverty (AWPI score ranges into six categories as described in Table 3). The values of this index vary from 38.51-56.03 across the province. 
Table 3. Classifications of the Agricultural Water Poverty Index.

\begin{tabular}{ccc}
\hline & Definition & Range \\
\hline 1 & Drastic agricultural water poverty & $0-30$ \\
2 & High agricultural water poverty & $30.01-40$ \\
3 & Upper middle agricultural water poverty & $40.01-50$ \\
4 & Lower middle agricultural water poverty & $50.01-60$ \\
5 & Low agricultural water poverty & $60.01-70$ \\
6 & Agricultural water wealth & $70.01-100$ \\
\hline
\end{tabular}

Source: Heidecke (2006); Lawrence et al. (2002); Forouzani et al. (2013).

An analysis of different components of AWPI is presented in Table 4. The results obtained for the surface water resources show that Nahavand with a score of 92.63 is in a better condition than the other counties in terms of surface water resources status.

Table 4. The values of components and sub-components of AWPI Index according to different counties.

\begin{tabular}{|c|c|c|c|c|c|c|c|c|c|c|c|c|}
\hline & \multirow[b]{2}{*}{ County } & \multicolumn{3}{|c|}{ Resources } & \multicolumn{3}{|c|}{ Access } & \multicolumn{4}{|c|}{ Capacity } & \multirow[b]{2}{*}{ 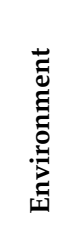 } \\
\hline & & 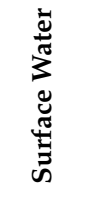 & 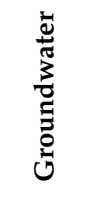 & 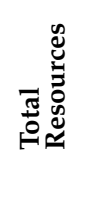 & 离 & 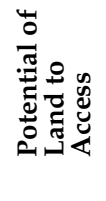 & 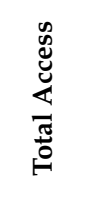 & Use & 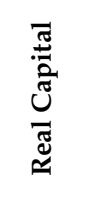 & 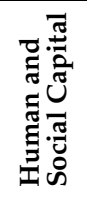 & 宽 & \\
\hline 1 & Hamedan & 0.97 & 41.42 & 27.53 & 38.53 & 39.61 & 38.99 & 56.52 & 42.18 & 57.93 & 46.86 & 62.50 \\
\hline 2 & Malayer & 27.04 & 38.03 & 34.25 & 48.98 & 32.52 & 41.80 & 14.65 & 29.15 & 28.63 & 28.99 & 69.47 \\
\hline 3 & Nahavand & 92.63 & 27.59 & 49.92 & 21.42 & 39.03 & 29.10 & 43.18 & 46.61 & 38.12 & 44.08 & 45.52 \\
\hline 4 & Toyserkan & 60.55 & 35.10 & 43.84 & 41.72 & 36.64 & 39.50 & 71.02 & 41.81 & 27.09 & 37.43 & 81.85 \\
\hline 5 & Kabudarahang & 15.96 & 50.15 & 38.41 & 38.36 & 23.00 & 31.65 & 29.15 & 59.06 & 31.70 & 50.92 & 55.77 \\
\hline 6 & Asadabad & 25.24 & 43.10 & 36.97 & 48.55 & 71.41 & 58.53 & 47.73 & 45.93 & 39.79 & 44.10 & 55.32 \\
\hline 7 & Bahar & 14.84 & 33.81 & 27.29 & 22.65 & 20.46 & 21.69 & 48.73 & 45.51 & 76.53 & 54.74 & 61.17 \\
\hline 8 & Razan & 33.32 & 48.41 & 43.23 & 74.48 & 49.35 & 63.52 & 36.91 & 48.16 & 35.08 & 44.27 & 43.78 \\
\hline 9 & Famenin & 11.21 & 68.23 & 48.65 & 37.00 & 21.68 & 30.32 & 25.45 & 55.79 & 21.35 & 45.55 & 44.51 \\
\hline 10 & Province & 33.34 & 24.04 & 27.61 & 43.32 & 32.15 & 38.44 & 40.44 & 36.00 & 38.80 & 36.83 & 56.02 \\
\hline
\end{tabular}

The lowest score belongs to Hamedan County (0.97), which indicates that Hamedan county as the provincial capital is very poor in terms of surface water resources.

The results obtained for the groundwater resources showed that only Famenin County with a score of 68.23 is above the mean. The status of counties in terms of resource component (surface water resources + groundwater resources) showed that Nahavand with the score of 49.92 had the best status.

The status of Hamedan province counties in terms of the Access component (Farmer Access to Water as well as the Land Potential for Access to Water) showed that Razan with a score of 63.52 and Asadabad with a score of 58.53 had the best water access status. The results of the sub-component of "Land Potential for Access to Water" also indicated that Asadabad with a score of 71.41 had the best status compared with other counties. In other words, the lands of Asadabad are under better conditions for water infiltration and conservation. The results of the Use component show that Toyserkan with a score of 71.02 had the best status compared with the other counties of Hamedan province. This means that farmers in this area have the best abilities for optimum and efficient use of water. The results of the Capacity component showed that Bahar with a score of 54.74 and Kabudarahang with a score of 50.92 had the best status. Malayer with the lowest score (28.99), is the poorest province county in terms of the Capacity component.

The results of the calculation of the "Real Capital" sub-component show that Kabudarahang with the score of 59.06 and Fameinin with the score of 55.79 had the highest score in this category. Therefore, the highest amount of investment in this category was made in Kabudarahang and Famenin. The results of the calculation of the sub-component of the "Human and Social Capital" also indicate that Bahar with a score of 76.53 and Hamedan with a score of 57.93 had good social and human capital for optimal water resources man- 
agement. The Environment component is the fifth and last component of the AWPI. The results of the Environment component show that Toyserkan with a score of 81.85 had the best status as compared with the other counties.

Moreover, the critical component (the most important cause of agricultural water poverty) has been addressed in each county (Figure 2).

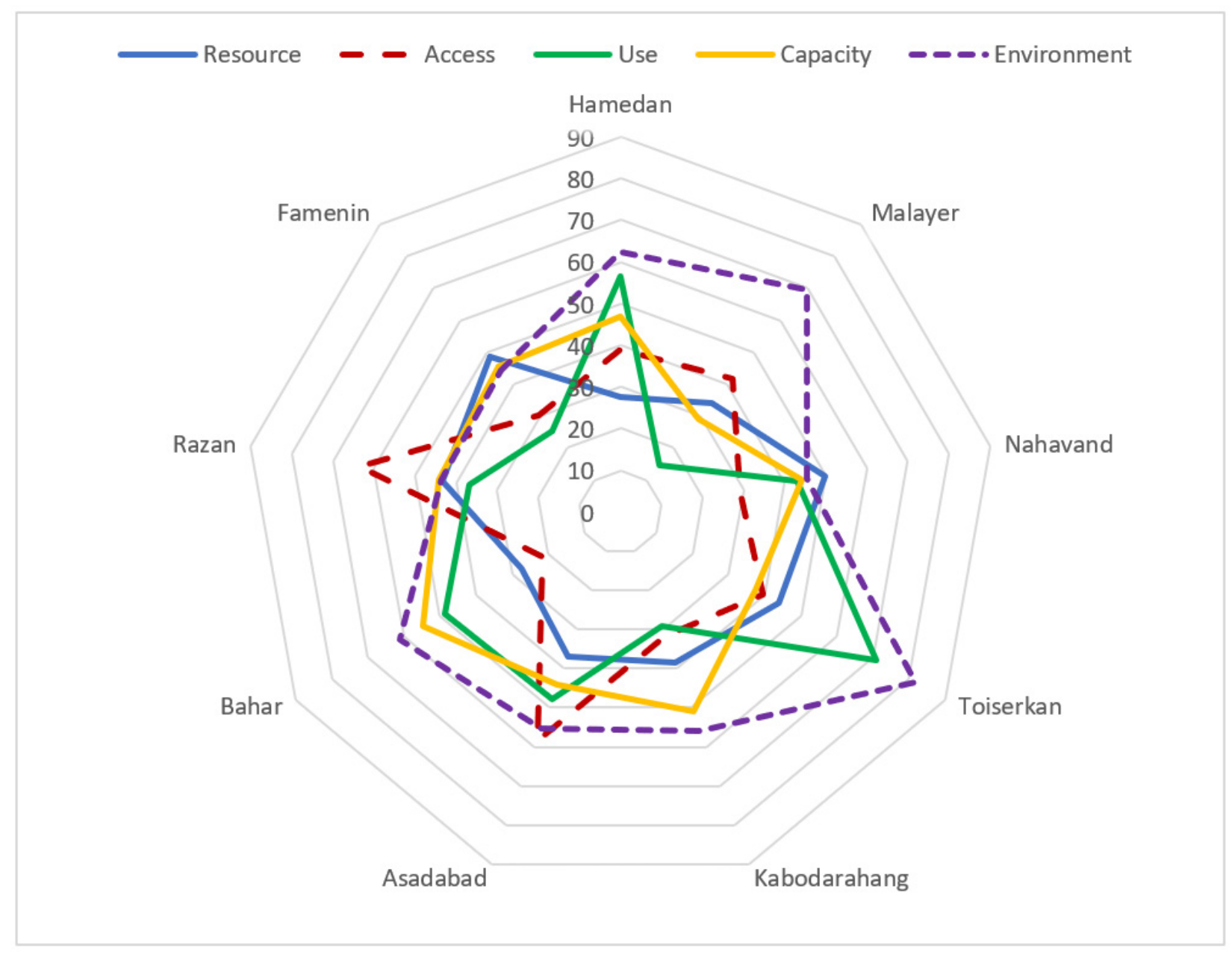

Figure 2. The status of components of of AWPI in different counties of the province.

\subsection{Classification of the Province Based on AWPI}

After calculating the AWPI, agricultural water poverty map was drawn based on the results (Figure 3) that show that Malayer and Famenin counties have the highest agricultural water poverty status and Toyserkan County had the lowest agricultural water poverty. The other counties of the province were classified as having "medium to high agricultural water poverty". 


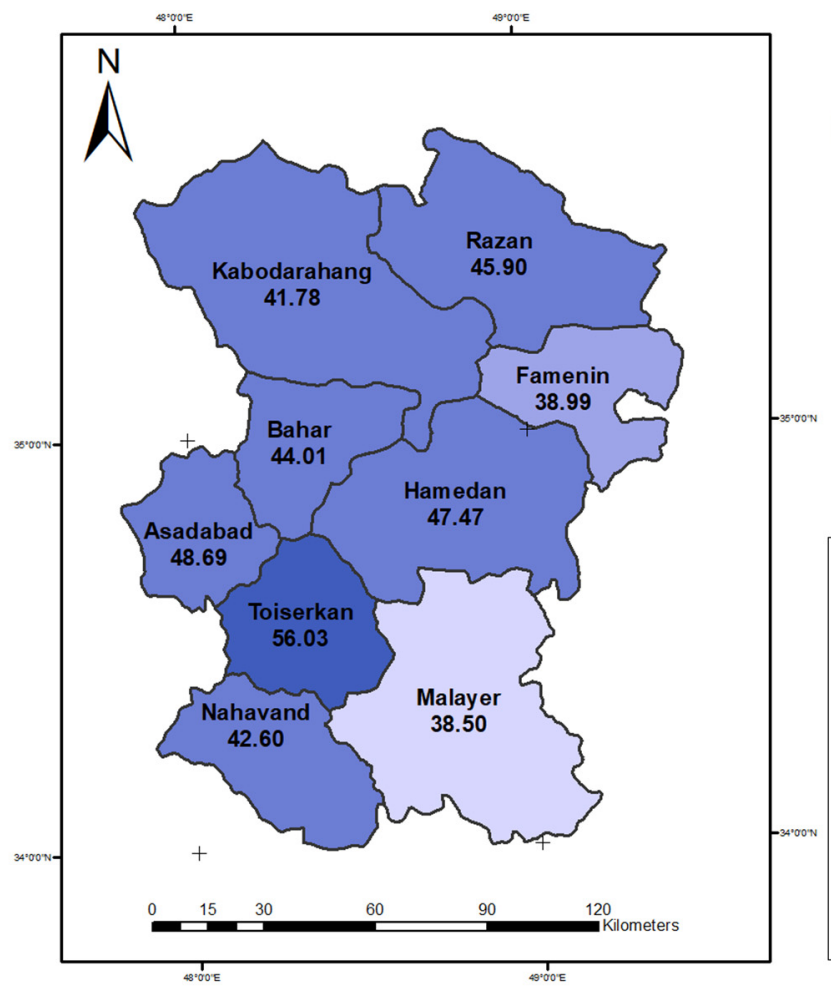

\author{
AWPI \\ in Hamedan Province \\ $1 \mathrm{~cm}=12.5 \mathrm{~km}$
}

\begin{tabular}{|c|c|}
\hline Color & AWPI Class \\
\hline & Drastic Agricultural Water Poverty \\
\hline & High Agricultural Water Poverty \\
\hline & Upper Middle Agricultural Water Poverty \\
\hline & Lower Middle Agricultural Water Poverty \\
\hline & Low Agricultural Water Poverty \\
\hline & Agricultural Water Wealth \\
\hline
\end{tabular}

Figure 3. The zoning of counties based on AWPI.

\title{
4. Discussion
}

WPI combines two components of the physical water availability with the people's capacity to access the resource, to assess the water scarcity [48]. In this study, using AWPI, the status of water resources in different counties of Hamedan Province was evaluated. The study results show that the AWPI in Hamedan province is in the middle to high water poverty categories. Zarafshani and Saadvandi [44], Forouzani, Karami, Zamani and Moghaddam [32], Manandhar, Pandey and Kazama [2,11,49], and Pandey, Manandhar and Kazama [7] also reported similar results.

In this study availability and variability of the water resources were known as the Resource component of AWPI. According to the results, the most important reason for water poverty in the agriculture sector of the province is related to the "Resource" component, so that the sub-component of "Groundwater Resources" accounts for more than half of the total amount of water poverty. Of course, this result is quite logical and justifiable, because most of the agricultural water of the province has been consumed.

Notably, the Resource component consists of both the availability of surface and groundwater. Any deficiency in these resources affects farmers' access to sufficient water. For example, low groundwater potential decreases the efficiency of springs and Qanats on which many livelihoods are dependent [50]. Hence, rainwater harvesting has been recommended as a solution to enhance the groundwater resource component [51]. In their study, Manandhar, Pandey and Kazama [11] and Shakya [15] concluded that the Resource component was the most important cause of water poverty in their studied areas. Also, the Resource component was found to have the most impact on the human resource index [52].

Capacity is the second component of agricultural water poverty in Hamedan province which accounts for nearly two-thirds of the total amount of water poverty. The score of this component is low among different counties which indicates the fact that in different counties of the province there are no appropriate social and institutional infrastructures for the efficient use of available water resources. This is consistent with the findings by Forouzani, Karami, Zibaei and Zamani [39], Yazdi, et al. [53], and Forouzani, Karami, Zamani and Moghaddam [32]. In the Capacity component, the greatest effect is made by 
the "Real Capital" indicator. Therefore, the real capital in the province in the field of water resources falls in an undesired status. Sullivan et al. (2006) also reported similar results in their study.

In the sub-component of Social and Human Capital, the most important factors that have led to the intensification of the phenomenon of water poverty include the lack of training courses held in the field of water management, the low level of membership of farmers in rural production, agriculture, and water use cooperatives. For this component (Capacity), the results show that Bahar county, especially based on social and human capacities, had the best conditions. This means that the farmers of this county in terms of attending the training courses held in the field of water management, literacy rate, the percentage of membership in cooperatives active in rural production, and the percentage of users of water organizations had proper conditions. However, they could not use water resources optimally, which lowered their water use efficiency in the area. Therefore, it is suggested that the farmers should get involved in the process of water governance, formulating rules, regulations, and policies in the field of water resources. This ensures that rules and regulations have better enforcement guarantees and have sufficient deterrence so that they ensure optimal monitoring and efficient use of water resources by farmers.

Access to sufficient and safe water is placed in the Access component of AWPI. For the Access component, the results show that the condition is not desirable. More than half of the total water poverty was related to the Access component. Hamedan province was found to be in the undesirable condition of Access component. This result is consistent with Wilk \& Jonsson (2013) and Ty et al. (2010). In the sub-component of "Farmer Access to Water", the most important factor affecting water poverty can be attributed to the percentage of inefficient and outdated irrigation systems. Currently, a significant part of irrigation systems in the province are damaged and do not have the required efficiency. The highest water loss is related to these systems problems, which greatly reduce water access efficiency. Inconsistent with the results of this section, a study by Yahaya et al. (2009) in the local areas of Oondo State in Nigeria and a study by Merz (2003) in Nepal showed fair access to water.

According to the study results, Hamedan province was in the range of "medium to high water poverty" of the "Use component." In other words, the province faces poverty, and water use efficiency is low. This result is consistent with the study results of Pandey et al. (2012). A study by Kiani Feyzabad, et al. [54] found that among the components, Resources and Use have the lowest values indicating the cause of instability in water resource management.

The environment was found to be a basic component of WPI under climatic and economic changes [43]. Hamedan is a province that has been severely exposed to climate change parameters and drought conditions. In line with current findings, another study reported that less developed countries in the MENA region are the most exposed to climate changes and severe water and food insecurity [55]. One of the most important causes of water poverty in this component is related to "irrigate lands covered by greenhouse." The study results show that in Hamedan province less than $1 \%$ of the land is covered by the greenhouse. However, in the greenhouse environment due to low use of water and mechanized irrigation systems, water use is minimized, and water use efficiency increases significantly. However, the study results indicate that Hamedan province was under proper conditions in the "Environment" component and was in the range of "less than moderate water poverty." Therefore, the resource, capacity, access, use, and environment components require immediate actions through resource management plans.

\section{Conclusions}

Based on the findings, priorities for intervention must be given to Malayer and Famenin regions with a low AWPI score which requires immediate attention. Therefore, the index is considered valid and appropriate for this issue because it corresponds to the realities of the regions. 
The severity of AWPI showed that the present policies and strategies have not been efficient enough and need to be re-visited. It is noticeable that water poverty management is a location- and group-specific issue which needs to take regional variations into account. The study indicates that some regions like Nahavand suffered from groundwater availability. Hence, it is suggested that the construction of water reservoirs and promotion of water productivity at the farm level be taken into account to address the water resource problems. Capacity is found as a crucial component of the water poverty index. It is recommended to provide supports to empower rural people in terms of health, education, and income. Diversification of economic activities and strengthening local organizations are two actions that help improve the capacity of farming communities to better manage water resources.

Improvement of water access needs advanced and innovative farming infrastructure and technologies. Provision of facilities and support to farmers for efficient water exploitation, transfer, and use will improve the Access component. These intervention programs should be aligned with food security and sustainable livelihood for poor people and regular access to sufficient water as a basic asset to secure farmers' life. Thus, to alleviate water poverty, it is crucial to prompt agricultural productivity and enhance the resilience of farming units without damaging the environment. The results indicate that there is an increasing need to formulate appropriate policies and strategies to improve water management indicators. Environment management is an important component of water poverty management. To mitigate the unpredictable and negative impacts of high rainfall variability and increasing temperature, the adaptive capacity of farmers needs to be enhanced. In addition, more sustainable and efficient farming practices should be implemented to upgrade the resilience of small-scale farming units.

The Resource and Capacity components should be paid immediate attention to protect farmers from the negative effect of water poverty. Marginalized rural groups such as women and small farmers are more susceptible to suffer from the negative impact of water poverty. Hence empowerment of these vulnerable groups through improving their access to water resources and their capacity to manage them is very essential. It is a social intervention that should be taken into consideration by the government and NGOs. The province was found to be under different levels of agricultural water poverty based on selected components. It is recommended that the government should take immediate actions to rescue the region from more water deprivation. Furthermore, the outcomes from this study enhance the developing body of knowledge of global and local WPI researchers and may motivate the water community, planner, and other water-related stakeholders to compute their AWPI situation and decrease environmental impacts to improve their plans and products.

Author Contributions: Conceptualization, K.N.M. and L.Z.S.; methodology, K.N.M. and L.Z.S.; software, L.Z.S. and M.M.; formal analysis, L.Z.S.; data curation, L.Z.S.; writing-original draft preparation, K.N.M.; writing-review and editing, H.S.F.; supervision, K.N.M.; project administration, K.N.M. All authors have read and agreed to the published version of the manuscript.

Funding: This research received no external funding but it has been carried out as a part of the doctoral dissertation in Bu-Ali Sina University.

Institutional Review Board Statement: Not applicable.

Informed Consent Statement: In the study, the authors received valuable consulting from Reza Movahdei.

Data Availability Statement: The data were collected from some known databases such as Agricultural Statistics, Agricultural Jihad Organization, Regional Water Company of Hamedan Province, and National censuses. Bu-Ali Sina University entitled: Designing a model for Sustainable management of agricultural water in the Hamedan province by L.Z.S.

Conflicts of Interest: The authors declare no conflict of interest. 


\section{References}

1. Liu, Z.; Liu, W. Spatial-temporal relationship between water resources and economic development in rural China based on poverty perspective. Int. ÁJ. ÁEnviron. ÁRes. ÁPublicáHealthá Á 2021, 18, 1540.

2. Koirala, S.; Fang, Y.; Dahal, N.M.; Zhang, C.; Pandey, B.; Shrestha, S. Application of water poverty index (wpi) in spatial analysis of water stress in Koshi river basin, Nepal. Sustainability 2020, 12, 727. [CrossRef]

3. Sullivan, C. Calculating a water poverty index. World Dev. 2002, 30, 1195-1210. [CrossRef]

4. $\quad$ Lawrence, P.R.; Meigh, J.; Sullivan, C. The Water Poverty Index: An International Comparison; Citeseer: Princeton, NJ, USA, 2002.

5. Komnenic, V.; Ahlers, R.; Van Der Zaag, P. Assessing the usefulness of the water poverty index by applying it to a special case: Can one be water poor with high levels of access? Phys. Chem. Earth Parts A B C 2009, 34, 219-224. [CrossRef]

6. Li, X.; Wan, J.; Jia, J.L. Application of the water poverty index at the districts of Yellow river basin. Adv. Mater. Res. 2011, 250, 3469-3474. [CrossRef]

7. Pandey, V.P.; Manandhar, S.; Kazama, F. Water poverty situation of medium-sized river basins in Nepal. Water Resour. Manag. 2012, 26, 2475-2489. [CrossRef]

8. Salameh, E. Redefining the water poverty index. Water Int. 2000, 25, 469-473. [CrossRef]

9. El-Gafy, I.K.E.-D. The water poverty index as an assistant tool for drawing strategies of the Egyptian water sector. Ain Shams Eng. J. 2018, 9, 173-186. [CrossRef]

10. Thakur, J.K.; Neupane, M.; Mohanan, A.A. Water poverty in upper Bagmati river basin in Nepal. Water Sci. 2017, 31, 93-108. [CrossRef]

11. Manandhar, S.; Pandey, V.P.; Kazama, F. Application of water poverty index (wpi) in Nepalese context: A case study of Kali Gandaki river basin (kgrb). Water Resour. Manag. 2012, 26, 89-107. [CrossRef]

12. Shah, T.; van Koppen, B. The precept and practice of integrated water resources management (iwrm) in India. In Indian Water Policy at the Crossroads: Resources, Technology and Reforms; Springer: Cham, Switzerland, 2016; pp. 15-33.

13. Van der Vyver, C. Water poverty index calculation: Additive or multiplicative function. J. South Afr. Bus. Res. 2013, $2013,1-11$.

14. Jemmali, H.; Matoussi, M.S. A multidimensional analysis of water poverty at local scale: Application of improved water poverty index for Tunisia. Water Policy 2013, 15, 98-115. [CrossRef]

15. Shakya, B. Analysis and Mapping Water Poverty of Indrawati Basin; World Wide Fund for Nature Nepal Report; WWF: Washington, DC, USA, 2012.

16. Yahaya, O.; Akinro, A.; Kehinde, O.; Ologunagba, I. Evaluation of water poverty index: In Ondo state, Nigeria. ARPN J. Eng. Appl. Sci. 2009, 44, 249-265.

17. Heidecke, C. Development and Evaluation of a Regional Water Poverty Index for Benin; International Food Policy Research Institute: Washington, DC, USA, 2006; Volume 145.

18. Srivastava, P.K.; Pandey, P.C.; Kumar, P.; Raghubanshi, A.S.; Han, D. Gis supported water use master plan: A planning tool for integrated water resources management in Nepal. In Geospatial Technology for Water Resource Applications; CRC Press: Boca Raton, FL, USA, 2016; pp. 27-50.

19. Cho, D.I.; Ogwang, T.; Opio, C. Simplifying the water poverty index. Soc. Indic. Res. 2010, 97, 257-267. [CrossRef]

20. Cullis, J.; Regan, D.O. Targeting the water-poor through water poverty mapping. Water Policy 2004, 6, 397-411. [CrossRef]

21. Han, H.; Zhao, L. Rural income poverty in western China is water poverty. China World Econ. 2005, 13, 76-88.

22. Van Ty, T.; Sunada, K.; Ichikawa, Y.; Oishi, S. Evaluation of the state of water resources using modified water poverty index: A case study in the Srepok river basin, Vietnam-Cambodia. Int. J. River Basin Manag. 2010, 8, 305-317. [CrossRef]

23. Feitelson, E.; Chenoweth, J. Water poverty: Towards a meaningful indicator. Water Policy 2002, 4, 263-281. [CrossRef]

24. Brooks, N.; Adger, W.N.; Kelly, P.M. The determinants of vulnerability and adaptive capacity at the national level and the implications for adaptation. Glob. Environ. Change 2005, 15, 151-163. [CrossRef]

25. Qiang, F.; Kachanoski, G.; Dong, L.; Zilong, W. Evaluation of regional water security using water poverty index. Int. J. Agric. Biol. Eng. 2008, 1, 8-14.

26. Bossio, D.; Geheb, K.; Critchley, W. Managing water by managing land: Addressing land degradation to improve water productivity and rural livelihoods. Agric. Water Manag. 2010, 97, 536-542. [CrossRef]

27. Mlote, S.D.; Sullivan, C.; Meigh, J. Water poverty index: A tool for integrated water management. In Proceedings of the 3rd Symposium on Water Demand Management for Sustainable Development, Dar es Salaam, Tanzania, 30-31 October 2002; pp. 30-31.

28. Lilienfeld, A.; Asmild, M. Estimation of excess water use in irrigated agriculture: A data envelopment analysis approach. Agric. Water Manag. 2007, 94, 73-82. [CrossRef]

29. Lorite, I.J.; Mateos, L.; Orgaz, F.; Fereres, E. Assessing deficit irrigation strategies at the level of an irrigation district. Agric. Water Manag. 2007, 91, 51-60. [CrossRef]

30. Van Cauwenbergh, N.; Biala, K.; Bielders, C.; Brouckaert, V.; Franchois, L.; Cidad, V.G.; Hermy, M.; Mathijs, E.; Muys, B.; Reijnders, J. Safe-A hierarchical framework for assessing the sustainability of agricultural systems. Agric. Ecosyst. Environ. 2007, 120, 229-242. [CrossRef]

31. Forouzani, M.; Karami, E. Agricultural water poverty index and sustainability. Agron. Sustain. Dev. 2011, 31, 415-431. [CrossRef]

32. Forouzani, M.; Karami, E.; Zamani, G.H.; Moghaddam, K.R. Agricultural water poverty: Using q-methodology to understand stakeholders' perceptions. J. Arid Environ. 2013, 97, 190-204. [CrossRef] 
33. Mehta, L. The manufacture of popular perceptions of scarcity: Dams and water-related narratives in Gujarat, India. World Dev. 2001, 29, 2025-2041. [CrossRef]

34. Hemmati, B.; Forouzani, M.; Yazdanpanah, M.; Khosravipour, B. Comparison application of the analytic network process (anp) and analytic hierarchy process (ahp) in analysis of the agricultural water poverty index: The case of dezful county. Iran. Agric. Ext. Educ. J. 2016, 11, 203-221.

35. Fenwick, C. Identifying the Water Poor: An Indicator Approach to Assessing Water Poverty in Rural Mexico; UCL (University College London): London, UK, 2010.

36. Wilk, J.; Jonsson, A.C. From water poverty to water prosperity-A more participatory approach to studying local water resources management. Water Resour. Manag. 2013, 27, 695-713. [CrossRef]

37. Franklin, S.E. Remote Sensing for Sustainable Forest Management; CRC Press: Boca Raton, FL, USA, 2001.

38. Garriga, R.G.; Foguet, A.P. Unravelling the linkages between water, sanitation, hygiene and rural poverty: The wash poverty index. Water Resour. Manag. 2013, 27, 1501-1515. [CrossRef]

39. Forouzani, M.; Karami, E.; Zibaei, M.; Zamani, G.H. Agricultural water poverty index for a sustainable world. In Farming for Food and Water Security; Springer: Cham, Switzerland, 2012; pp. 127-155.

40. Huang, Q.; Rozelle, S.; Lohmar, B.; Huang, J.; Wang, J. Irrigation, agricultural performance and poverty reduction in China. Food Policy 2006, 31, 30-52. [CrossRef]

41. Mwakalila, S. Socio-economic impacts of irrigated agriculture in Mbarali district of south-west Tanzania. Phys. Chem. Earth Parts $A / B / C$ 2006, 31, 876-884. [CrossRef]

42. Sullivan, C.A.; Meigh, J.R.; Giacomello, A.M. The Water Poverty Index: Development and Application at the Community Scale; Natural Resources Forum; Wiley Online Library: Hoboken, NJ, USA, 2003; pp. 189-199.

43. Jaren, L.S.; Mondal, M.S. Assessing water poverty of livelihood groups in peri-urban areas around Dhaka under a changing environment. Water 2021, 13, 2674. [CrossRef]

44. Zarafshani, K.; Saadvandi, M. Determining agricultural water poverty index in kermanshah province: The case of Mahidasht basin, Iran. J. Agric. Sci. Technol. 2017, 19, 541-552.

45. OJHP. A Brief Report on Basic Statistics of Hamadan's Agriculture; Organization of Jihad-Agriculture in Hamadan Province (OJHP): Kashan, Iran, 2021; pp. 61-142.

46. Garriga, R.G.; Foguet, A.P. Improved method to calculate a water poverty index at local scale. J. Environ. Eng. 2010, 136, 1287-1298 [CrossRef]

47. Kallio, M.; Guillaume, J.H.; Kummu, M.; Virrantaus, K. Spatial variation in seasonal water poverty index for laos: An application of geographically weighted principal component analysis. Soc. Indic. Res. 2018, 140, 1131-1157. [CrossRef]

48. Prabha, A.S.; Ram, A.; Irfan, Z.B. Exploring the relative water scarcity across the indian million-plus urban agglomerations: An application of the water poverty index. HydroResearch 2020, 3, 134-145. [CrossRef]

49. Ifabiyi, P.; Oladele, B.; Salau, W. Water poverty assessment in olorunsogo local government area of Oyo state, Nigeria. Geosfera Indones. 2020, 5, 92-105. [CrossRef]

50. Khadka, G.; Pathak, D. Groundwater potential as an indicator of water poverty index in drought-prone mid-hill region of Nepal Himalaya. Groundw. Sustain. Dev. 2021, 12, 100502. [CrossRef]

51. Yadav, G.S. Estimation of water scarcity in Bundelkhand region of Madhya Pradesh: An inter-district analysis. Int. J. Appl. Soc. Sci. 2020, 7, 524-537.

52. Ladi, T.; Mahmoudpour, A.; Sharifi, A. Assessing impacts of the water poverty index components on the human development index in Iran. Habitat Int. 2021, 113, 102375. [CrossRef]

53. Yazdi, N.; Mousavi, S.N.; Shirvanian, A.; Zarei, A.R. Assessing the effects of climate and drought changes on the water poverty index in the Fasa plain. Irrig. Water Eng. 2021, 11, 289-304.

54. Kiani Feyzabad, Z.; Yazdani, S.; Salami, H.; Peykani, G.R. Analyze and identification components of instability in Iranian basins (application of water poverty index in basin scale). Iran. J. Agric. Econ. Dev. Res. 2021, 42. [CrossRef]

55. Jemmali, H.; Morrar, R.; Ben Aissa, M.S. The dynamic nexus between climate changes, agricultural sustainability and food-water poverty in a panel of selected mena countries. J. Water Clim. Change 2021, 12, 1-17. [CrossRef] 